\author{
A.M. Morosh ${ }^{1}$, N.E. Tarasovskaya ${ }^{1}$, G.K. Kabdolova ${ }^{1 *}$, \\ Sh.Sh. Khamzina ${ }^{2}$, S.A. Solovyev ${ }^{3}$ \\ ${ }^{I}$ NJSC «Pavlodar Pedagogical University», Pavlodar, Kazakhstan; \\ ${ }^{2}$ Innovative Eurasian University6 Pavlodar, Kazakhstan; \\ ${ }^{3}$ Omsk State University named after F.M. Dostoevsky ${ }^{3}$ Omsk, Russia \\ (*Corresponding author'E-mail: gulzhan_city@mail.ru) \\ ORCID: 0000-0003-2490-1391
}

\title{
The use of multilingualism in excursion classes in biology (on the example of the greenhouse of the children's and youth center for ecology and tourism)
}

\begin{abstract}
Education is an area of social and cultural human's life, which is made becoming spiritually mature, highly moral person, able to defend the universal, common cultural values. Education is impossible without accomplishment, and accomplishment should be targeted. Multicultural component in the educational system of any educational institution at the moment is vital, especially in our multinational country. A special place in the education of children and adolescents take humanities, and in particular the study of foreign languages by children. At the present stage in the conditions of intercultural communication is becoming increasingly common model of multilingual education. In this regard, the fundamental purpose of education should be training people in the new model of development of the international community based on universal, global values, the formation skills in children and teens to communicate and interact with representatives of neighboring cultures and in space. Educational institutions not only provide the necessary general and professional knowledge, but also to translate socio-cultural values form the patterns of behavior and skills of intercultural communication, contribute to the formation of an international, multi-cultural identity of the individual.
\end{abstract}

Keywords: multilingualism, excursion classes, biology lessons, greenhouse, children's and youth center, communication and activity operations, regional component, intersubject relations.

\section{Introduction}

In the conditions of innovative development of education the main goal is to build a model of learning, which would create the conditions for the adoption by teachers of new ideas, approaches, new features and ways of pedagogical activity, one of which is the introduction of multilingual education in subjects of natural - mathematical cycle [1;3].

The first President of the country, N.A. Nazarbayev, set a fairly high bar for national education. Education should become competitive, high-quality, so that graduates of the Kazakh school can easily continue their studies in foreign universities. The introduction of three-language education in the educational process of a comprehensive school is, of course, a significant step forward in the implementation of the Concept of Education Development of the Republic of Kazakhstan, one of the basic competencies of which is trilingualism.

Trilingualism is a necessity that the head of our state spoke about in his Address. The widespread translation of office work into the state language requires deep knowledge of it, for the integration of Kazakhstan into the world space, you need to know English, and Russian is necessary as a language of interethnic communication $[2 ; 25]$.

The main goal facing teachers and students of schools is the development of a multicultural personality who knows the customs and traditions of his people, speaks several languages, is able to carry out communicative and activity operations in three languages, and strives for self-development and self-improvement.

Knowledge of Kazakh, Russian and foreign languages is becoming an integral component of the personal and professional activities of mankind in modern society. All this in general causes the need for a large number of citizens, practically and professionally, who speak several languages and receive, in this regard, real chances to take a more prestigious position in society, both socially and professionally.

In the annual Address of the President of the Republic, the need for multilingual education, active introduction of foreign languages into the Kazakh reality is noted, since trilingualism should be encouraged at the state level. In addition, training in three languages, and, as a result, their knowledge is almost perfect, 
will contribute to familiarizing with the culture and traditions of different peoples. And this is the formation of a multilingual personality [3-5].

\section{Materials and methods}

The question here is: what can each subject teacher really do in their school? Any discipline, including natural science, can be made a means of learning a language, and at the same time, the assimilation of terminology provides excellent opportunities for not mechanical, but conscious learning of foreign and other nonnative languages. A significant role in the development of words and phrases of a non-native language can be played by various communicative moments of lessons or group work with students [6;343].

During the lesson, various forms of inclusion of material in three languages are used, for example, to create a psychological mood. During the lesson - this is working with text information, reading, translating, retelling. Such types of work best allow you to increase your vocabulary in biology.

Multilingualism for me is not only a high goal set by our first president, and to which everyone should strive. The concept of «multilingualism» for me as a teacher is also filled with some aspects of the professional plan. Namely:

- Implementation of interdisciplinary connections in the classroom, integration;

- Expanding students ' horizons and cultural enrichment by mastering three languages;

- Education of tolerance and internationalism.

The main task at the initial stage of work on the development of multilingualism is to show children that languages, although limited by the time of the lesson, can be a means of communication and transmission of information. Students have a very strong motive of curiosity about languages, a great desire to communicate with each other. And I am convinced that it is possible and necessary to use this psychological feature when teaching languages $[7 ; 23]$.

In the classroom, I post the topic and goal on the board in three languages, so that students can see what we will learn and what the teacher and students need to achieve by the end of the lesson.

At the organizational stage of the lesson, the children and I greet each other in three languages, then when conducting a psychological mood, I conduct various trainings with the introduction of a multilingual component, for example: «Greeting», «Acquaintance», «Wishes for today»:

Қайырлы таң!

Қайырлы таң саған!

Қуаныштымыз саған!

Good morning!

Good morning to you.

We are glad to see you!

Children are offered a communicative situation; a meeting at an international conference of citizens of Kazakhstan, Russia and the UK, leaving the children the freedom to choose phrases for building communication.

Thus, several variants of polylogues are obtained.

While learning new material, I use various active learning methods:

- associative series;

- reference synopsis;

- INSERT (interactive writing system for effective reading and reflection);

- brainstorming;

- group discussion;

- clusters;

- cinquain;

- key terms;

- didactic game;

- working with tests;

- non-traditional forms of homework.

As for physical education minutes, now there are a variety of thematic electronic physical minutes, which can also include elements of multilingualism.

At the stage of mastering new knowledge, students are offered a glossary of terms in three languages (English, Russian, Kazakh) with transcription, which they should know. A glossary is a dictionary of highly 
specialized terms in any branch of knowledge with interpretation, sometimes translations into another language, comments and examples. If you need to check the pronunciation of a word in English, you can listen to it online $[8 ; 1]$

The selection of multilingual text material for the middle and older age groups can be carried out according to such criteria as:

- Accessibility from the point of view of language means,

- Relevance of the problem from the standpoint of universal values and from the point of view of modern problems,

- Compliance with the speech and life experience of students.

Ecological school (Children and Youth Center of Ecology and Tourism) provides special opportunities for creative learning of foreign languages (especially English). And this possibility, in our opinion, lies in the rational organization of excursions to nature and the greenhouse - so that these excursions are filled not only with natural science, but also with linguistic content. Of course, this will require special erudition and reading skills from the biology teacher, as well as consultations with philologists (teachers of Russian, Kazakh, and foreign languages). But properly prepared summaries of such excursions, built taking into account the age and outlook of students, will be of methodological value and used by many teachers for the real implementation of interdisciplinary connections $[9 ; 60]$.

We have compiled several notes of such excursions-on herbaceous and woody-shrubby plants, on the names of invertebrates and vertebrates available for observation. But the most interesting was our methodological work on the organization of linguistic excursions to the greenhouse and arboretum on the territory of Children's and Youth Center for Ecology and Tourism [10;362].

\section{Results and discussion}

The greenhouse is a subject of special pride for teachers and students involved in environmental circles. The names of exotic plants are remembered by students of teenage and high school is not so easy and simple. Most often, they are well known to those students who create something in the greenhouse with their own hands and take a constant part in the care of plants. But it is the names of exotic flowers that can reveal not only natural science, but also language talents in our students. By teaching students to think about words, we will give them not only an interesting and meaningful hobby, expand their horizons, but, perhaps, give someone a start in life as a future scholar-philologist.

Here are just some fragments of our linguistic tours of the greenhouse, which are of the greatest interest to the circle members and visitors. And it turns out that some of the inhabitants of the greenhouse are quite ordinary houseplants and have students at home. But not everyone thought about why these plants are called that way.

Jade tree (Crassula arborescens). This plant is known to many, often lovingly called the money tree. Compare the English crass (coarse, large, also translated as ignorant) and the Russian word beautiful (which can also be ascribed not only to the word red: in ancient times, it was a full person who was considered beautiful, especially a woman). Thick this plant, like other representatives of this family, did not become from a good life: the supply of moisture and dissolved nutrients in the leaves is important when living in arid conditions. The species definition of arborescens has many single-root words in Russian and English. Compare arbor-wood, forest, bor-northern type of forests, boreas-north wind.

Cordyline fruticosa (Cordyline fruticosa). This exotic plant has the same Russian, Latin and English names. The reason for this is a straight hard stem: the word cord means wire. Compare also the term chord (in zoology and mathematics. The species definition of fruticosa is similar to the English fruit and the Russian word fruit (literally - fruits that grow on branches).

Prickly pear (Opuntia monacantha). This cactus with prickly broad leaves is found in many homes and institutions, but not everywhere it reaches such a huge size as in our greenhouse eco-school. The name of this cactus, which is decorative in our country and has become an ecological disaster for Australia, is the same in all languages. The generic Latin definition of monacantha is easy to decipher: mono-one (compare: monopod, monologue, monk); The name of the type of Acanthocephala is skrebni (literally «spiny-headed»), acanthella (larva of Acanthocephala), acantharia (order of radiolarians with mineral needles), acanthodes (extinct spiny-toothed fish), acantholimon (plant of the family Plumbaginaceae).

Eucharis (Eucharis). Not everyone knows that this plant with beautiful white flowers is called that. The beautiful Latin generic name of the plant goes back to ancient Greek: eu - good, real (remember eukaryotes, eustela, eutrophication); charis-love (compare-charisma, the Latin name of Hydrocharis). 
Asparagus Sprenger thick-flowered (Asparagus densiflorus «Sprengeri»). This is a common asparagus, which is known to everyone, not only as a houseplant, but also as a wild plant, as well as a well-known kitchen seasoning. From the generic Latin name asparagus comes the Russian name asparagus and the family asparagus. The Latin root itself (meaning spreading, as well as spreading) is included in the name of another plant from the cattail family-sparganum (hedgehog). Compare also the English words sparge-sprinkle, sparger-sprinkler). The Latin generic definition also has roots in many well - known words: English dense dense, dense, density-density; compare also the words flora, floristics. And the Russian name Frol was originally written as Flor and meant «flower».

Gloxinia (Gloxinia). Gloxinia will not surprise even an ordinary housewife. This plant of the Gesneriaceae family is widespread in culture all over the world. The Latin generic (and quite similar Russian) name means bell, bell (due to the corresponding shape of the flower). Compare the German Glockebell, bell, bell, English clock-alarm, alarm; also English glossal (related to the language), glossary (dictionary), and also compare the Russian words voice, voice, vowel.

Nephrolepis. The name of this famous fern, which is the same in Russian and Latin, can be deciphered without difficulty if you remember the famous words with similar roots: nephron, nephrite (not only kidney disease, but also mineral), as well as the Old Russian word «lepota» (meaning beauty), the modern word ridiculous (with the original meaning of clumsy, ugly).

Epipremnum Golden (Epipremnum aureum). From the generic name of this plant, everyone knows the element epi -: epilogue, epicrisis, epistolary. Let's also compare the words premium, premium. The species name needs no special interpretation: everyone knows that aurum is the chemical name for gold. The name of the jellyfish aurelia means golden. Let's try to find more words of the same root: aura, aurora-with the meaning of shine, radiance.

Found in our greenhouse and such a popular middle-class flower as ficus-ficus rubber (Ficus elastica). Ficus is the same name in all languages of the world: as an indoor decorative and as a rubber-bearing plant, it has been known for a long time. However, similar words-phycomycetes (water fungi), phycobionts, phycocyanins go back to another Greek root Phycos - algae. Although it is possible that these names are related: ficuses live in humid conditions and liberally secrete a liquid-milky juice. But the specific definition of elastica, hinting at its rubber-bearing properties, is heard in such well-known words as elastic, elastic. Compare also the school name of the eraser eraser.

The most common aloe (Áloë vera), which is difficult to surprise anyone, in our greenhouse was in the place of honor. And it can not only surprise, but also make you think, especially future philologists. The Latin generic name of this plant, the same in all languages (and came from scientific Latin, and there-from Arabic), is known to everyone. Let's compare the Kazakh word al, meaning power, strength, abilities (as well as alem-world and the word element). The plant was indeed attributed not only medicinal properties, but also miraculous, supernatural power. But as for the Latin specific definition of vera with the meaning true, real, it makes us doubt that the word faith (and the name Faith) is purely Russian. It is a Latin root that has left its mark in many words of European languages. Compare words such as version, verification, verdict (literallythe true word). And even the English word very with the meaning very, strongly, extremely has to do with this root (strongly, excessively — means really).

Fuchsia magellanica (Fuchsia magellanica). This plant then goes out of fashion, then again finds itself on the crest of popularity. But it is difficult to remain indifferent to its bright flowers. With the specific name of the plant, everything is clear: it indicates a geographical point - the Magellanic Islands (named after the famous circumnavigator). And the generic name of the flower itself-fuchsia, fuchsia-can be compared with the name of the famous dye - fuchsin, as well as the brown algae fucus.

Coleus Blum (Coleus Blumeli). Who does not know this completely harmless «nettle» with colored leaves! This plant is called the same in Russian and English (in fact, it copies the scientific Latin name). It is also interesting to compare the English words: cole - cabbage garden, cole-rape-kohlrabi (the Russian name of this vegetable crop comes from English), cole-seed-surepka, cruciferous weed, cole-slaw-salad of shredded cabbage. By the way, coleus is bred not only and not so much as an ornamental, but as an edible plant (especially the variety that is called - coleus edible). It is used for food leaves, but especially-nutritious and rich in starch underground parts.

Aspidistra high (Aspidistra eliator) it is also available in many homes and institutions. The English word aspidistra translates as Asian lily of the valley (and, quite likely, means this particular genus of monocotyledonous plants of the amaryllis family, which originates from Central Asia). The Latin species definition is comparable to the word elevator, as well as the English words elevator, elevate - to lift up. 
Hydrangea macrophylla (Hydrangea macrophylla) is familiar to many. We can easily translate the species name into Russian: macro-means everything big (compare: macroeconomics, macroscopic), phyllum means leaf (compare: bryophyllum, phylloids, phyllocladia). But the words hydrangea and hydrangea (equal synonyms) are in Russian and English, as well as in Latin. Compare the English words horticulturegardening, horticulture, ortolan-garden bunting (with the loss of the first letter; the Latin name of this bird is Emberiza hortulans).

Lemon (Cítrus límon) grows not only in our greenhouse, but also in many lovers of indoor plants. Everyone is familiar with the words citrus and lemon. There are also Russian and English words lime (meaning also cultivated citrus fruit). But let's remember that the lemon root (which is both in Latin and in European languages) is part of the names of plants in the family of lead: Goniolomon, Limonium (kermek). Apparently, it means a tart taste, and also goes back to the word lime - lime. Only here in English this word is written as lemon - when mastering the word, a vowel was replaced.

Zantedeschia Ethiopian (Zantedeschia). About this well-known plant is worth saying especially. In everyday life, it is called calla, but in fact calla is a white-winged marsh and bears the Latin name Calla palustris. This plant also belongs to the family Araceae, but to a different genus. In the same way as under the name of asters, we have everywhere bred callistephus Chinese. So these two flowers can go down in the history of gardening with their incorrect, but well-established names. And the name callistephus in translation from ancient languages literally means a beautiful wreath (compare: calligraphy and the name Stefan, Stepan with the meaning of a crown).

Alocasia macrorrhizos (Alocasia macrorrhizos). The plant has an exotic name, but in appearance is familiar to many. The specific Latin name is easily deciphered: macro-means large, large (as opposed to micro -); rhizome - rhizome. Compare the English word rhizome with the meaning of root, rhizome, underground part; also the terms rhizoids (analogs of roots in mosses), rhizomoids. We also compare the Kazakh word riza - prostration, riza - long clothes of priests, the saying «to drink up to the position of riz» (that is, to lie on the ground).

Kalanchoe (Kalanchoe). This is an extensive group of species in the family tolstyankovyh, of which many are bred as ornamental and used as medicinal (the juice of these plants has an antimicrobial effect). The generic name is probably a word of Arabic origin. With kalanchoe, the genus bryophyllum is often combined, which forms brood buds on leaves (bryophyllum literally translates as moss on a leaf; compare: bryology — the science of mosses, the word shave-to deprive outgrowths).

Abutilon (indoor maple) (Callianthe picta), (Abutilon picta). The word abutilon itself sounds the same in many languages: this culture is known all over the world not only and not so much as decorative, but as fibrous. Its other generic name Callianthe can be deciphered based on the well-known words: it literally means «beautiful flower». Let's remember the word «calligraphy» - the art of writing beautifully, the name Anton with the meaning of flower, Anfisa (Antisa) - blooming, the term anthodium - an inflorescence resembling a single flower. And now it is enough to compare the generic name picta and the English word picture-picture, then you can understand that in all the names we are talking about a beautiful flower.

Austrocylindropuntia subulata. The word prickly pear as the name of the cactus that gave rise to an environmental disaster in Australia is known to everyone. But this is not just a prickly pear, and judging by the complex name, it is also cylindrical (the word cylinder is the same in all languages), and also southern (compare the toponyms Austria, Australia). The specific Latin name subulata is very similar to the English word subulate and means awl-shaped (it is in the botanical description of plants, and not in the name of the instrument).

Acanthocereus (Acanthocereus). Cereus - a group of cacti with ribbed spiny stems. Compare also the words: ceramides, ceramics, keratin-with the general meaning of hard, hard, and also the Latin generic name of cherries Cerasus, English cherry. Russian words cherries and cherries (fruits with a hard stone). Acanto means prickly, and we are already familiar with this word from some previous names — there are many prickly plants in the plant world.

Some cacti have beautiful and exotic names, for example, Astrophytum asterias. Apparently, this cactus is so starry or starry that this root is repeated in the generic and specific name, in Russian and Latin versions. The roots of Astron, Aster means «star». Compare the words astronomy, astral, the name of the plant aster, the name Esther, as well as the English word star and the German Stern. The root «fitum» is also quite easy to decipher - it means a plant: compare-herbal tea, herbal medicine.

And here is another cactus of the same kind, Astrophytum decorated (Astrophytum capricorne). This cactus has the same «star» generic scientific name as the previous one. But the species definition means, on 
closer examination, goat horns. Compare the Latin name of the nightjar Caprimulgus, the goat willow Salix caprea, the rye affected by ergot horns Secale cornutum («horned rye»), the English corn with the meaning of kernel, grain, popcorn, German Kern. Compare Latin cornutum and Russian roots (horns and roots have a common meaning - as outgrowths).

Ferocactus (Ferocactus). The word cactus (prickly ball) is known to all, and with the word fero-it will mean «bearing cactus». Compare the words: pheromones, transferases, interferon.

Spotted petal or graptopetalum (Graptopetalum). Compare the first root of the generic name and the Russian words krap, speckled. Compare also the Latin name of the group of orders Rosaceae razdelnolepestnye Melophyta choripetalae. And then everything with the name of the plant will become clear.

Ochitok (Sédum). Sedum acris (Sedum acris) in the wild flora grows in the mountains and foothills; this species, and a number of other tropical species are used as decorative. The generic name of the plant can be etymologically reduced to the words sedentary, meeting (meaning-attached), as well as sedative. The species name of the wild stonecrop acris literally means caustic. Compare the name of the right-winged insect acrid (it, unlike other locusts, does not eat greens, but insects), the English word acrid with the meaning of caustic.

Pachypodium Lamerei (Pachypodium lamerei). The generic name of this plant in Russian should be translated literally as «thick-legged». Compare the word podium, the name of the plant podophyll, the species name of Sophora pachycarpa, the Russian words pakhi, plow, smell (clothes - that is, put one part of the clothes on another).

Euphorbia triangular (Euphórbia trígona). The generic name Euphorbia can be traced in the name of a poisonous alkaloid characteristic of all euphorbiaceae-euphorbin. Compare the Greek element eu - (meaning good, real-for example, eukaryotes) and the English word forbid-prohibition, refusal (that is, the general meaning-a truly forbidden, poisonous plant). And the specific Latin definition of trígona is translated as triangular; compare-trigonal, hexagonal, Pentagon (a well-known administrative building of a pentagonal shape).

The Chinese hibiscus (Hibiscus rosa-sinensis). This houseplant of the malvaceae family is familiar to everyone. In English, this plant is also called hibiscus. The Russian name Chinese rose was given to the plant because of its Eastern origin and some external similarity of the double flower with a rose. It should be noted that the word rose (of Latin origin) sounds about the same in all languages of the world (remember the English rose).

Begonia (Begonia), of course, is familiar to everyone. And this is an extensive group of plants, many of which are bred in culture as ornamental. They quickly multiply by shoots and even parts of the leaf. Compare the Russian words run, escape.

Hippeastrum reddish (Hippeastrum). In this case, the ancient (Greek) element hippus means a horse, a horse: remember the hippodrome, hippocampus, the name Philip-with the meaning of a lover of horses, fossil horses merigippus and hipparion, hip-hop dance, the English word hip-hip (in horses, the most active part of the body is the hip). And the word aster means star; this root is also evident in the words astronomy, astrology.

Hymenocallis (Hymenocallis). The generic name of this plant can be deciphered as «the owner of a beautiful veil». The word hymen means the hymen, Hymen - the deity of the marriage bond. Well, the well-known word calligraphy means penmanship. Yes, we also recall that the correct botanical name of the garden aster is callistephus, literally-the owner of a beautiful wreath (the name Stepan, Stefan means a wreath, a crown).

Lime (Citrus aurantiifolia) - this source of refreshing drink also settled in our greenhouse. Compare the word lime (of English origin) and the Russian lemon: they mean citrus fruit. And the species name aurantiifolia can be deciphered as the owner of shiny or golden leaves. Remember aurum-the chemical symbol of gold, aura-the golden glow, aurora-the dawn. The Latin root «folium» with the meaning of leaf is also familiar to everyone; it is easily listened to in words such as folio (thick volume), defoliants (means for removing leaves).

Lemon callistemon (Callistemon citrinus). The ancient basis of «calli», as you know, means beautiful (remember calligraphy - the art of beautiful writing). Compare the English word stem — stem, trunk. The Latin species name citrinus is similar to the Russian «lemon»: after all, lemon refers to citrus fruits and bears the Latin generic name citrus.

Podlesna butcher's broom (Ruscus hypophyllum). The generic name of this plant can easily be deciphered by any sufficiently well-read person: hypo-means under, below a certain level, phylum-leaf. It is 
enough to recall the words hypothermia (low temperature), hyposomy (low body weight), phyllocladia (needle-like leaves), phyllocactus.

Clivia cinnabar (Clívia miniáta). Clivia is a genus of evergreen plants in the Amaryllis family. Compare the English words clive, cleave - split, stick or stay true. Compare the English word miniate-paint with cinnabar, decorate with colored drawings, as well as the word miniature (a small color picture). Cinnabar is a sulfide of mercury - bright red or orange paint.

Pentas lanceolate (Pentas lanceolata). The name of the surgical instrument lancet is the same in both Russian and Latin. Think also of the lanceolates - simply arranged chordal creatures that resemble this instrument in appearance. And the generic name Pentas literally means five, five-fold: indeed, the flower has five large, well-defined petals. Think also of pentane, the Pentagon.

Nematanthus (Nematanthus). The name in translation into Russian can be deciphered as a thread-like flower. Compare the name of the class of roundworms - nematodes (literally - filamentous), the name of the stages of prophase of the first division of meiosis-leptonema, pachinema, zygonema. And now compare the names Anton (flower), Anfisa (blooming), the term anthodium (inflorescence resembling a separate flower).

Pedilanthus tithymaloides (Euphorbia tithymaloides). Euphorbia is a common name for the genus euphorbia. It can be traced in the name of a poisonous alkaloid peculiar to all euphorbiaceae-euphorbin. Compare the Greek element eu - (meaning good, real-for example, eukaryotes) and the English word forbidprohibition, refusal (that is, the general meaning-a truly forbidden, poisonous plant). But the second generic synonym - Pedilanthus-can mean flowers on the stem. Compare the English words (scientific terms of Latin origin) pedicel - stem, pedicel, pedicellate-stem. Let us also compare the pedestal (pedestal), and in general words with the Greek basis of ped-, meaning both foot, stand, and heir. Recall the names Anton, Anfisa, the term anthodium (type of inflorescence). The specific definition of titimaloid can go back to the words titillate-tickle, pleasantly arouse, titivate — preen, and mean gentle, pleasant.

Eupatorium (Eupatórium). A very interesting generic name, which is immediately associated with the name of the famous resort town of Yevpatoria (which literally translates as a health resort). Let's decipher this word with the ancient basics: eu-good, real; and also compare the words pathology, pathogenesis, pathetics. In general, it turns out recovery. And we can also add that this word means the generic Latin name of the hemp seedling from the family of compound flowers-Eupatorium cannabinum, and is found in the species name of the medicinal turnip Agrimonia eupatoria.

Syngonium podophyllum (Syngonium podophyllum). It seems like a simple flower, but with an exotic name. This plant can easily decipher both species and generic names, having at least a minimal vocabulary in the field of scientific terms. Sin-together (compare: synchronous), gonium - angle (compare: hexagonal hexagonal). And who does not know the word podium! Everybody knows the words Triphyllios (trefoil), Ferocactus (leaf cactus), phylloclades (the leaves transformed into spines).

Naked bougainvillea (Bougainvillea glabra). In the generic name of Bougainvillea, you can see the English word village(village, village), also compare with the word villa (country cottage) and villans (the word meaning peasants is known from historical literature, for example, the novels of M. Druon). And this is a really beautiful arbor plant. The specific definition of glabra with the meaning smooth, naked appears in the Latin names of other plants. For example, licorice naked Glycyrrgiza glabra, smooth Herniaria glabra. The English word glabrous means smooth, bald, hairless.

Jacaranda (Jacaranda). This genus of plants belongs to the family of the figwort order bignonieae. These trees and shrubs (and their 30-40 species) are common in the tropics of Latin America. Let's think about where the name jacaranda (or yakaranda) comes from. Obviously, from the proper name - Jacquard, Jacques. And this is nothing but the French version of the Russian name Yakov (Polish name Yakub, Turkic Zhakup or Yakup). This name, which has traveled all over the world, originates in Semitic (or other Eastern) languages and means heel (that is, the second twin that appeared on the heels of the first). Let us also compare the Kazakh word ayak-leg and the original version of the reading of this name (which is also found in the Synodal translation of the Bible) - Jacob.

The whip-like aporocactus (Aporocactus flagelliformis). The word cactus does not need to be deciphered: everyone knows these rounded prickly plants. But the specific Latin definition is worth thinking about, remembering similar words: the Latin name of flagellates Flagellata, flagellants (sect of selfflagellators), also flag (fluttering, waving). And the word form is familiar to all, and it is the same in all languages (coming to us from Latin). 
Pilea (Pilea). The generic name of this plant literally means hairy. Compare: depilation (a cosmetic procedure for removing hairs from the body), the term pili, meaning sexual hairs, copulatory fimbriae in bacteria, pilidium-free-floating larvae of nemertinus from the order heteronemertinus (and in translation from ancient Greek, the word pilidium literally means felt hat).

There is also such an exotic plant in our greenhouse as Arabian coffee (Coffea arábica), although everyone knows and loves the products from it. The name of this plant and drink sounds the same in all languages and countries of the world. The culture itself (a tree of the madder family) came from Ethiopia and was successfully naturalized in Latin America. The name of the Arabian Peninsula and the word Arab come from the same root.

And here is another guest from the usual kitchen-the noble laurel, which in our greenhouse is humorously called the «sausage tree». In Latin, it is called Laurus nobilis. The Russian and Latin names are quite similar. And add the romantic name Laura - it means nothing more than a laurel tree. The species definition is associated with the Nobel Prize and the name of Alfred Nobel-by coincidence, a truly noble wealthy man who founded the foundation for the support of scientists and artists. Compare also this species definition in the Latin names of other plants: for example, Hepatica nobilis.

\section{Conclusion}

Thus, specially selected linguistic material and its skillful presentation on excursions arouse increased interest among visitors to the greenhouse, and also open up further opportunities for cooperation between teachers of different specialties - linguists and teachers of the natural and mathematical cycle. And Children's and Youth Center for Ecology and Tourism as an extracurricular educational institution can become an excellent base for organizing such ecological and linguistic excursions.

\section{References}

1 Темиргазина 3. Навстречу полиязычному образованию / 3. Темиргазина, Ж. Абильдинова // «Ұстаздар» газеті. 2015. - C. 3 .

2 Аскапова Р.Р. Полиязычие как одно из приоритетных направлений развития педагогического образования / Р.Р. Аскапова, А.М. Сыздыкова // Пед. вестн. Казахстана. — 2014. — № 2. - С. 25-31.

3 Послание Президента Республики Казахстан Н.А. Назарбаева «Социально-экономическая модернизация - главный вектор развития Казахстана». [Электронный ресурс]. — Режим доступа: http://adilet.zan.kz/

4 Концепция развития образования Республики Казахстан на 2011-2020 гг. [Электронный ресурс]. - Режим доступа: http://adilet.zan.kz/

5 Послание Главы государства «Стратегия Казахстан - 2050: новый политический курс состоявшегося государства» [Электронный ресурс]. - Режим доступа: http://adilet.zan.kz/

6 Жетписбаева Б.А. Полиязычное образование: теория и методология / Б.А. Жетписбаева. — Алматы: Білім, 2008. $343 \mathrm{c}$.

7 Александрова Е.В. Виртуальная экскурсия как одна из эффективных форм организации учебного процесса на уроке литературы / Е.В. Александрова // Литература в школе. - 2010. — № 10. — С. 22-24.

8 Баженова Н.А. Виртуальная экскурсия как одна из эффективных форм организации образовательного процесса на основе ЭОР / Н.А. Баженова // Открытый урок. — 2015.

9 Дашкова Е.В. Особенности организации экскурсий для современных школьников / Е.В. Дашкова, Е.Б. Ивушкина // Педагогика и современность. - 2014. - Т. 1, № 1-1. - С. 60.

10 Семенов А.А. Теория и методика организации учебно-воспитательного процесса в школе при изучении биологии на основе электронных ресурсов / А.А. Семенова, Е.А. Макарова // Изв. Самар. науч. центра РАН. — 2009. — № 4 (2). — C. $362-366$.

\section{А.М. Морош, Н.Е. Тарасовская, Г.К. Кабдолова, Ш.Ш. Камзина, С.А. Соловьев}

\section{Биологиядан экскурсиялық сабақтарда көптілділікті қолдану (Балалар мен жасөспірімдердің экология және туризм орталығының оранжереясы мысалында)}

Білім - бұл адамның әлеуметтік-мәдени өмірінің саласы, онда жалпыадамзаттық, жалпы мәдени құндылықтарды қорғауға қабілетті рухани жетілген, жоғары адамгершілік тұлға қалыптасады. Жетістіктерсіз білім алу мүмкін емес, ал жетістіктер мақсатты болуы керек. Қазіргі уақытта кез-келген оку орнының білім беру жүйесіндегі көп мәдениетті компонент өте маңызды, әсіресе біздің көпұлтты 
елімізде. Балалар мен жасөспірімдерге білім беруде гуманитарлық және жаратылыстану ғылымдары, атап айтқанда балалардың шет тілдерін үйренуі ерекше орын алады. Қазіргі кезенде мәдениетаралық коммуникация жағдайында көптілді білім беру моделі кеңінен таралуда. Осыған байланысты білім берудің негізгі мақсаты адамдарды жалпыадамзаттық, жаһандық құндылықтарға негізделген әлемдік қоғамдастық дамуының жаңа моделіне үйрету, балалар мен жасөспірімдерде көрші мәдениеттер өкілдерімен және кеңістікте қарым-қатынас жасау және өзара іс-қимыл жасау дағдыларын қалыптастыру. Білім беру мекемелері қажетті жалпы және кәсіби біліммен қамтамасыз етіп қана қоймайды, сонымен қатар әлеуметтік-мәдени құндылықтарды таратады, мәдениаралық қарымқатынас мінез-құлқы мен дағдыларын қалыптастырады, тұлғаның халықаралық, көп мәдениетті өзіндік санасын қалыптастыруға ықпал етеді.

Кілm сөздер: көптілділік, экскурсиялық сабақтар, биология сабақтары, оранжерея, балаларжасөспірімдер орталығы, коммуникативті-әрекеттік операциялар, аймақтық компонент, пәнаралық байланыстар.

\title{
А.М. Морош, Н.Е. Тарасовская, Г.К. Кабдолова, Ш.Ш. Камзина, С.А. Соловьев \\ Применение полиязычия на экскурсионных занятиях по биологии (на примере оранжереи Детско-юношеского центра экологии и туризма)
}

\begin{abstract}
Образование - это область социокультурной жизни человека, в которой осуществляется становление духовно зрелой, высоконравственной личности, способной отстаивать общечеловеческие, общекультурные ценности. Образование невозможно без достижений, а успехи должны быть целенаправленными. Поликультурная составляющая в системе образования любого учебного заведения на данный момент является жизненно важной, особенно в нашей многонациональной стране. Особое место в образовании детей и подростков занимают гуманитарные и естественные науки и, в частности, изучение детьми иностранных языков. На современном этапе в условиях межкультурной коммуникации все более распространенной становится модель полиязычного образования. В связи с этим основополагающей целью образования должно стать обучение людей новой модели развития мирового сообщества, основанной на общечеловеческих, глобальных ценностях, формирование у детей и подростков навыков общения и взаимодействия с представителями соседних культур и в пространстве. Образовательные учреждения не только обеспечивают необходимыми общими и профессиональными знаниями, но и транслируют социокультурные ценности, формируют образцы поведения и навыки межкультурного общения, способствуют формированию интернационального, поликультурного самосознания личности.
\end{abstract}

Ключевые слова: полиязычие, экскурсионные занятия, уроки биологии, оранжерея, детско-юношеский центр, коммуникативно-деятельностные операции, региональный компонент, межпредметные связи.

\section{References}

1 Temirgazina, Z., \& Abildinova, J. (2015). Navstrechu poliiazychnomu obrazovaniiu [Towards multilingual education] «Ustazdar» hazeta - Teachers ' Newspaper, 3 [in Russian].

2 Askapova, R.R., Syzdykova, A.M. (2014). Poliiazychie kak odno iz prioritetnykh napravlenii razvitiia pedahohicheskoho obrazovaniia [Multilingualism as one of the priority directions of development of pedagogical education] Pedahohicheskii vestnik Kazakhstana - Pedagogical Bulletin of Kazakhstan, 2, 25-31 [in Russian].

3 Poslanie Prezidenta Respubliki Kazakhstan N.A. Nazarbaeva «Sotsialno-ekonomicheskaia modernizatsiia — hlavnyi vektor razvitiia Kazakhstana» [Address of the President of the Republic of Kazakhstan N.A. Nazarbayev «Socio-economic modernization — the main vector of development of Kazakhstan»]. adilet.zan.kz. Retrieved from http://adilet.zan.kz/ [in Russian].

4 Kontseptsiia razvitiia obrazovaniia Respubliki Kazakhstan na 2011-2020 hh. [Concept of Education development of the Republic of Kazakhstan for 2011-2020]. adilet.zan.kz. Retrieved from http://adilet.zan.kz/ [in Russian].

5 Poslanie Hlavy hosudarstva «Stratehiia Kazakhstan - 2050: novyi politicheskii kurs sostoiavshehosia hosudarstva»[Address of the Head of State "Strategy Kazakhstan-2050: a new political course of the established state»]. adilet.zan.kz. Retrieved from http://adilet.zan.kz/ [in Russian].

6 Zhetpisbaeva, B.A. (2008). Poliiazychnoe obrazovanie: teoriia i metodolohiia [Multilanguage education: theory and methodology] Bilim - Knowledge, Almaty, 343 [in Russian].

7 Aleksandrova, E.V. (2010). Virtualnaia ekskursiia kak odna iz effektivnykh form orhanizatsii uchebnoho protsessa na uroke literatury [Virtual excursion as one of the effective forms of organization of the educational process at the literature lesson] Literatura $v$ shkole - Literature at school, 10, 22-24 [in Russian].

8 Bajenova, N.A. (2015). Virtualnaia ekskursiia kak odna iz effektivnykh form orhanizatsii obrazovatelnoho protsessa na osnove EOR [Virtual excursion as one of the most effective forms of organizing the educational process based on EOR] Otkrytyi urok - Open lesson [in Russian].

9 Dashkova, E.V. (2014). Osobennosti orhanizatsii ekskursii dlia sovremennykh shkolnikov [Features of organizing excursions for modern schoolchildren] Pedahohika i sovremennost - Pedagogy and modernity, 1, 60 [in Russian]. 
A.M. Morosh, N.E. Tarasovskaya, et al.

10 Semenov, A.A., \& Makarova, E.A. (2009). Teoriia i metodika orhanizatsii uchebno-vospitatelnoho protsessa v shkole pri izuhenii biolohii na osnove elektronnykh resursov [Theory and methodology of the organization of the educational process at school in the study of biology on the basis of electronic resources] Izvestiia Samarskoho nauchnoho tsentra Rossiiskoi akademii nauk Proceedings of the Samara Scientific Center of the Russian Academy of Sciences, 4 (2), 362-366 [in Russian]. 